\title{
Preface: The Law of the Good Neighbor
}

In the fall of 1974 Giorgio Agamben traveled to London for a year of study in the library of the Warburg Institute. Dedicated to Kulturwissenschaft, the scholarly investigation of the arts and sciences, the library's most striking feature was its principle of organization. Works were not classified by subject, author, title, or even date of acquisition, but instead by what the library's founder, Aby Warburg, called "the law of the good neighbor." Although grouped under such general rubrics as anthropology and art history, both the various sections and the books within them were arranged according to their ability to engage with the books on either side of them. A line of speculation opened in one volume was attested to or attacked, continued or contradicted, refined or refuted in its neighbor. Each book was to answer or ask a question of the one next to it. ${ }^{1}$

Visitors to Warburg's library were thus confronted by an enigmaso intensely that upon first entering it Ernst Cassirer declared that one needed either "to flee from it" or "to remain there a prisoner for years" (he did both). ${ }^{2}$ Agamben's readers, if on a far smaller scale, are confronted by a similar problem. Just as readers like Cassirer-and later Agamben himself-found themselves inquiring into the hidden connections between the works in Warburg's library, so too do readers of Agamben's books. From The Man Without Content (1970) to Signatura rerum (2008), Agamben's eighteen works have proved, in Warburg's sense of the term, good neighbors to one another, both in that they ask and answer questions of one another, and in that these questions are not immediately apparent. Although Agamben has often remarked that what goes unsaid in one of his works provides the point of departure for what is said in another, he has not traced these lines nor, more generally, stressed what links his diverse writings. This at once personal and methodological choice leaves to his readers the task of connecting his interests and investigations, and 
makes it all too easy for them to miss the continuity and coherence that characterize his work.

The following pages are meant to elucidate that continuity—and to do so for two separate and distinct audiences. For readers possessing little or no familiarity with Agamben's writings I have attempted to provide points of entry for exploring them, and for those who are already well acquainted with Agamben's thought and its contexts I present a critical analysis of his works and of his conception of the work. This dual purpose has required that I walk a fine line between oversimplification and impenetrability. About this I cannot say more than that I hope to have strayed from it as seldom as possible.

Because of Agamben's singular manner of approaching the questions that interest him, I have chosen to follow his thought as it developed, proceeding from his first writings in the mid-rg6os to those of the present day. This principle of organization, however, is joined to another. Chapters One through Nine treat major works in the order of their publication; other parts of the book approach Agamben's philosophy thematically. The introduction presents Agamben's central idea-potentialityalongside the related idea of vocation. This thematic organization also appears in the many scholia offered at the ends of the chapters; in Chapter Ten's exploration of the ideas of messianism, the sacred, and the profane; and in the Conclusion's discussion of creation and completion. Ideally the marrying of these two principles of organization-chronology and terminology - allows the reader to proceed from beginning to end as well as to read chapters or scholia in isolation. This has required that I walk a different but equally fine line-one between incomprehensibility and redundancy_ and here too I can say only that I have endeavored to waver as little as possible.

The only worthwhile reason for writing a book on a single author is that one finds that author fascinating, and I would indeed never have written the following pages were I not fascinated by their subject. This does not mean, however, that I agree with all of Agamben's views, or that I think every one of his works worthy of his gifts. More to the point, it is not my intention to defend his writings against all criticisms. My goal instead is to present something of his works' diversity and continuity. In some cases this has resulted in my concurring with Agamben's critics; in others, in my taking issue with them. The general rule I have followed 
is to invoke them where I felt it might lead to a better understanding of Agamben's thought. This engagement with secondary sources markedly increases as the book progresses for the simple reason that the critical literature on Agamben's early works is sparse and the critical literature on his later works is ample. For this same reason I have concentrated on summary and elucidation more in the chapters on lesser-known early works than in those on later ones, such as Homo Sacer, for which summaries are in rich supply.

The reader will not be long in noting that philological questions play a large role in this study. Paraphrasing Wittgenstein, Agamben has often argued that "philosophical problems become clearer if they are formulated as questions concerning the meaning of words" (P, I77 [273]; see also PP, 77). The idea that philosophical questions are inseparable from philological ones is central to this work, not only because the idea is Agamben's own, but also because of the many points of uncertainty surrounding even the most fundamental terms in his writing.

A final word on length: this book will seem long-and doubtless all the more so given that Agamben's books have, as a rule, been short; but they have also been many, and their concerns have been remarkably diverse-and it is to that diversity that this study responds. 
GIORGIO AGAMBEN 
